\title{
Effects of Aroclor 1254 and vitamin $E$ on arginase activity in adult, pregnant rats and their offsprings
}

\author{
Ayşe DOĞAN ${ }^{1}$, Mine ERIşíí ${ }^{2}$ \\ ${ }^{1}$ Bitlis Eren University, Academy of Medicine, Department of Physiotherapy and Rehabilitation, Bitlis; ${ }^{2}$ Firat University, Faculty of \\ Veterinary Medicine, Department of Biochemistry, Elazig, Turkey.
}

\begin{abstract}
Summary: This study examined the effect of Aroclor 1254 on arginase activity and protective role of vitamin E among adult rats, pregnant rats and their offsprings. Totally 90 Sprague-Dawley rats were divided into three main groups as 30 pregnant, 30 adult and 30 offsprings (pups of the pregnant rats) based on the treatments administered during the pregnancy period (20 days) with subcutaneous daily injections of Aroclor 1254 (2 mg/kg/day) alone or associated with vitamin E (50 mg/kg/day) or normal saline in controls. Female rats and their offsprings (10 offsprings per groups) were analyzed in terms of the arginase activity in liver. A statistically significant increase was determined in liver arginase activity of adult rats exposed to Aroclor 1254 ( $p<0.05)$. Vitamin E administered simultaneously with Aroclor enabled liver arginase activity of adult rats to approach statistically normal values. A statistically insignificant increase was found in the arginase activity among pregnant rats and offsprings. While vitamin E administered simultaneously with Aroclor was ineffective in pregnant rats, it caused a statistically significant increase in offsprings $(p<0.05)$. We recommend that addition of vitamin E can prevent the increase in the liver arginase activity caused by Aroclor 1254 .
\end{abstract}

Keywords: Arginase, Aroclor 1254, offspring, pregnant, vitamin E.

\section{Aroclor 1254 ve vitamin E'nin yetişkin, gebe rat ve yavrularında arginaz aktivitesi üzerine etkileri}

Özet: $\mathrm{Bu}$ çalışmada yetişkin, gebe rat ve yavrularında arginaz aktivitesi üzerine Aroclor 1254'ün etkisi ve vitamin E'nin koruyucu rolü araştırıldı. Toplam 90 Sprague-Dawley rat 30 yetişkin, 30 gebe ve 30 yavru olmak üzere üç ana gruba ayrıldı. Gebelik süresince (20 gün) subkutan olarak Aroclor 1254 (2 mg/kg/gün) tek başına veya vitamin E (50 mg/kg/gün) ile birlikte ve kontrol grubuna serum fizyolojik uygulandı. Dişi ratlar ve onların yavrularının (her gruptan 10 yavru) karaciğerinde arginaz aktivitesi analiz edildi. Aroclor 1254'e maruz kalan yetişkin ratların karaciğer arginaz aktivitesinde anlamlı bir artış ( $\mathrm{p}<0.05)$ belirlendi. Aroclor 1254 ile birlikte vitamin E uygulanan yetişkin ratların arginaz aktivitesi istatistiksel olarak normal değerlere yaklaştı. Gebe ratlar ve yavrularının arginaz aktivitesinde istatistiksel olarak anlamsız bir artış tespit edildi. Aroclor 1254 ile birlikte vitamin $\mathrm{E}$ uygulanması gebe ratlarda etkili olmasa da; yavru ratlarda anlamlı bir artışa $(\mathrm{p}<0.05)$ sebep olmuştur. Vitamin E ilavesinin, Aroclor 1254 'ün sebep olduğu karaciğer arginaz aktivitesindeki artışı önleyebildiğini önermekteyiz.

Anahtar sözcükler: Arginaz, Aroclor 1254, gebe, vitamin E, yavru.

\section{Introduction}

Polychlorinated biphenyls (PCBs) are halogenated aromatic hydrocarbons that were produced for industrial purposes and are now known as persistent environmental pollutants $(1,4)$. Their common usages are industrial fluids, flame-retardants, diluents, and fluids for capacitors and transformers (15). They have a tendency of bioaccumulation both in the environment and living organisms because of their lipophilic features and chemical stability $(28,32)$. It has been reported that PCBs have various adverse effects on human health including carcinogenicity, endocrine disruption, neural, immune, developmental and reproductive toxicity $(17,27,31)$

Since Arginase (L-arginine amidinohydrolase, EC 3.5.3.1) catalyses the hydrolysis of L-arginine to L-ornithine and urea in the final cytosolic step of the urea cycle, it exists mainly in the liver. This reaction provides the principal route in order to dispose nitrogenous waste from protein catabolism (26). The liver is the main target organ for PCBs in the body as they are detoxified here (22). PCBs are known to cause hepatotoxicity $(17,18,23)$. Serum arginase activity increases in benign and malignant liver diseases (7).

Some studies have proved that there are some relationships between vitamin $\mathrm{E}$ and arginase. Park and Tappel (25) reported that rats fed with a vitamin supplemented diet had a lower liver arginase activity compared to those fed with a diet not containing vitamin E. Additionally, administration of dietary vitamin $\mathrm{E}$ caused a significant decrease in the liver arginase activity increased due to high doses of prednisolone in rats (12). 
PCBs transfer to foetus and to newborn by means of placenta and milk, respectively $(2,21,30)$. Aroclor 1254 is also known to be a dangerous environmental pollutant for offsprings $(5,6)$. There is no study investigating the effect of Aroclor 1254 on liver arginase activity. Therefore, the purpose of this study was to examine the effect of Aroclor 1254 on arginase activity and protective role of vitamin $\mathrm{E}$ among adult rats, pregnant rats, and their offsprings.

\section{Materials and Methods}

Experimental design: Totally 90 female SpragueDawley rats having a weight between 150-180 g were used in the study. The rats were kept in cages ( $n=5$ per cage) at standard temperature $\left(21 \pm 1^{\circ} \mathrm{C}\right)$ in a 12:12 light/dark cycle. Once the sexual cycle periods and/or pregnancy were determined according to the vaginal smear method, rats were randomly divided into groups based on chemical treatments and physiological status. Groups 1 and 4 served as nonpregnant $(n=10)$ and pregnant $(n=15)$ controls and were administered with normal saline subcutaneously for 20 days, respectively. While in groups 2 (nonpregnant females, $n=10$ ) and 5 (pregnant females, $n=15$ ), only Aroclor 1254 was subcutaneously administered to females at $2 \mathrm{mg} / \mathrm{kg} /$ day for 20 days (since the first day of pregnancy in pregnant rats); in groups 3 (nonpregnant females, $n=10$ ) and 6 (pregnant females, $n=15$ ), vitamin $E$ $(50 \mathrm{mg} / \mathrm{kg} /$ day) were administered with the Aroclor 1254. The last groups (groups 7, 8 and 9) corresponded to offsprings (10 in each group) from the control pregnant females, from females only administered with Aroclor 1254, and from females administered with Aroclor 1254 and vitamin E, respectively. On the day 20, liver tissue of 10 rats from each group was extracted during deep ether anaesthesia, and 5 females of each pregnant group were kept with their offsprings for four weeks. Liver tissue of the offsprings (10 in each group) was extracted at the end of the $4^{\text {th }}$ week by using deep ether anaesthesia. Liver tissue samples were stored at $-80^{\circ} \mathrm{C}$ until analysis. Permission of ethics committee regarding the animal experiments was received for this study (Firat University, Faculty of Medicine, Experimental Animal Research Ethic Committee).

Organs were excised and rinsed by using cold saline $(0.9 \% \mathrm{NaCl})$. After the tissues were weighed, they were homogenized with 10 volumes of $10 \mathrm{mM}$ Tris- $\mathrm{HCl}$ buffer $\mathrm{pH}$ (7.4) in glass Potter Elvehjem homogenizer in an ice bath. The homogenates were centrifuged at $20000 \mathrm{~g}$ for 10 min at $4{ }^{\circ} \mathrm{C}$. The supernatants were used in order to carry out assay of the arginase activities.

Arginase activity: Measurement of arginase activity was performed by specifying an increase in the amount of urea (the reaction product) (14). One unit (U) of enzymatic activity was defined as $\mu \mathrm{mol}$ of the product formed per hour at $37^{\circ} \mathrm{C}$. The results are presented as $\mathrm{U} / \mathrm{mg}$ protein. The protein content of tissue samples was analyzed by using the method of Lowry et al. (19). Bovine serum albumin was used as the standard.

Statistical analysis: The statistical analysis was carried out by using SPSS package program (10.0 for Windows). All results were shown as mean \pm SEM. The value of $p \leq 0.05$ was accepted as statistically significant. After normality test, analysis of variance (ANOVA) conducted by using Duncan test was used to determine if or not there was a significant difference among groups.

\section{Results}

A statistically significant increase was detected in the liver arginase activity of control rats exposed to Aroclor 1254 compared to control group $(\mathrm{p}<0.05)$. Vitamin $\mathrm{E}$ administered simultaneously with Aroclor enabled the liver arginase activity of control rats to approach statistically normal values (Table 1). A statistically insignificant increase was determined in arginase activity of pregnant rats and offsprings. While vitamin E administered simultaneously with Aroclor was ineffective in pregnant rats, it caused a statistically significant increase in offsprings A1254 + vitamin E group compared to offsprings control group ( $\mathrm{p}<0.05)$ (Tables 1 and 2).

Table 1. Liver arginase activities of adult and pregnant rats administered Aroclor 1254 (A1254) (2 mg/kg/day) and vitamin E (50 $\mathrm{mg} / \mathrm{kg} /$ day).

Tablo 1. Aroclor 1254 (A1254) (2 mg/kg/gün) and vitamin E (50 mg/kg/gün) uygulanan yetişkin ve gebe ratların karaciğer arginaz aktiviteleri.

\begin{tabular}{|c|c|c|c|c|c|c|c|}
\hline Parameter & Control & A1254 & $\begin{array}{c}\text { A1254 } \\
+ \text { Vitamin E }\end{array}$ & $\begin{array}{c}\text { Pregnant } \\
\text { Control }\end{array}$ & $\begin{array}{l}\text { Pregnant } \\
\text { A1254 }\end{array}$ & $\begin{array}{c}\text { Pregnant } \\
\text { A1254 } \\
+ \text { Vitamin E }\end{array}$ & $\mathrm{P}$ \\
\hline $\begin{array}{l}\text { Arginase } \\
\text { (U/mg } \\
\text { protein) }\end{array}$ & $240.09 \pm 9.57^{\mathrm{a}}$ & $365.47 \pm 25.14^{b}$ & $289.48 \pm 11.70^{\mathrm{ab}}$ & $270.79 \pm 63.15^{a b}$ & $292.31 \pm 31.52^{\mathrm{ab}}$ & $288.70 \pm 28.53^{\mathrm{ab}}$ & $\mathrm{P}<0.05$ \\
\hline
\end{tabular}

a, b: The difference between means that had different letters in the same line was statistically significant.

Values are means \pm SEM.

a, b: Aynı satırdaki farklı harflerin ortalamaları arasındaki farklılık istatistiksel olarak anlamlıdır.

Değerler, ortalama \pm standart hata şeklindedir. 
Table 2. Liver arginase activities of offsprings administered Aroclor 1254 (A1254) (2 mg/kg/day) and vitamin E (50 mg/kg/day). Tablo 2. Aroclor 1254 (A1254) (2 mg/kg/gün) and vitamin E (50 mg/kg/gün) uygulanan yavru ratların karaciğer arginaz aktiviteleri.

\begin{tabular}{|c|c|c|c|c|}
\hline Parameter & Offspring Control & Offspring A1254 & $\begin{array}{c}\text { Offspring A1254 } \\
\text { + vitamin E }\end{array}$ & $\mathrm{P}$ \\
\hline $\begin{array}{l}\text { Arginase } \\
\text { (U/mg protein) }\end{array}$ & $511.78 \pm 40.24^{\mathrm{a}}$ & $544.78 \pm 51.33^{\mathrm{ab}}$ & $627.66 \pm 28.70^{\mathrm{b}}$ & $\mathrm{P}<0.05$ \\
\hline
\end{tabular}

a, b: The difference between means that had different letters in the same line was statistically significant.

Values are means \pm SEM.

a, b: Aynı satırdaki farklı harflerin ortalamaları arasındaki farklılık istatistiksel olarak anlamlıdır.

Değerler, ortalama \pm standart hata şeklindedir.

\section{Discussion and Conclusion}

Persistent organic pollutants (POPs) are known to affect homeostasis and allostasis, which is the maintenance of a stable physiology. This is generally important for vital organ-system functioning as well as survival and reproduction in vertebrate species (29). The liver is the main target organ for PCBs in the body as they are detoxified here (22). Several studies indicate that PCBs cause hepatotoxicity and carcinogenicity as well as impairment in hepatic function $(17,18,23)$. In this study, a statistically significant increase was determined in the liver arginase activity of control rats exposed to Aroclor $1254(\mathrm{p}<0.05)$. Arginase catalyses the hydrolysis of Larginine to L-ornithine and urea. Also, some studies $(8,11$, 20) have revealed an increase in serum and urinary urea levels in PCB-exposed rats. The study conducted by Ebner and Couri (10) demonstrated that Aroclor 1254 exposure poised hepatic mitochondria toward the synthesis of urea intermediates such as carbamoyl phosphate, citrulline. However, arginase produces L-ornithine which acts as a biosynthetic precursor for proline, glutamate, and polyamines such as putrescine, spermine and spermidine. Polyamines are required for cell division, growth, and differentiation (3). The increase in the liver arginase activity of control rats exposed to Aroclor 1254 may result in an increase in cellular concentration of polyamines and also an increase in cell proliferation rate. With regard to all above-mentioned aspects, the increased arginase activity due to Aroclor 1254 may be important at the carcinogenicity caused by PCBs.

A statistically insignificant increase was found in the arginase activity of pregnant rats and offsprings. During pregnancy, the hepatic formation of urea is depressed (24) which causes a reduced urinary excretion (16). The preferential use of $\alpha$-amino acids for foetal protein synthesis would probably lead to reduce protein catabolism and nitrogen excretion in the maternal organism. This metabolic particularity would result from a down regulation of arginase or from a preferential alfaamino acids used for both growth of foetus in pregnant females and growth of their offsprings.
Vitamin E provides homeostasis in living cells (13). Some studies have proved that there were some relationships between vitamin $\mathrm{E}$ and arginase. Park and Tappel (25) reported that rats fed with a vitamin E supplemented diet for 40 days had lower liver arginase activity than those fed with a diet not containing vitamin E. Moreover, administration of dietary vitamin E caused a significant decrease in the liver arginase activity increased due to high doses of prednisolone in rats (12). We found in this study that administering vitamin $\mathrm{E}$ on rats simultaneously with Aroclor 1254 caused a decrease in liver arginase activity compared to the Aroclor 1254 group.

When we analyzed the effect of administering Aroclor 1254 and vitamin E simultaneously on the liver arginase enzyme activity in offsprings, interestingly it was determined that there was a statistically significant increase in the arginase enzyme activity of offspring A1254 + vitamin E group compared to the offspring control group. It is known that vitamin $\mathrm{E}$ is stored in placenta however its transfer to foetus is limited (9). The effect of vitamin $\mathrm{E}$ on arginase enzyme activity of offspring A1254 + vitamin E group may not have been detected, since the amount of administered vitamin E dose that is transferred to foetus was insufficient compared to the effect of Aroclor 1254.

Consequently, a statistically significant increase was detected in the liver arginase activity of control rats exposed to Aroclor 1254 in this study and administering vitamin E simultaneously with Aroclor 1254 was found to cause a decrease in liver arginase activity compared to the Aroclor 1254 group. We recommend that addition of vitamin $\mathrm{E}$ can prevent the increase in liver arginase activity caused by Aroclor 1254 .

\section{References}

1. Agency for Toxic Substances and Disease Registry (ATSDR): Toxicological Profile for Polychlorinated Biphenyls (PCBs) (2000): US Dept Health Services. Public Health Service, Atlanta.

2. Ando M, Saito H, Wakisaka I (1986): Gas chromatographic and mass spectrometric analysis of 
polychlorinated biphenyls in human placenta and cord blood. Environ Res, 41, 14-22.

3. Ash DE (2004): Structure and function of arginases. J Nutr, 134, 2760-2767.

4. Carpenter DO (1998): Polychlorinated biphenyls and human health. Int J Occup Med Environ Health, 11, 291-303.

5. Carpenter DO, Stoner CT, Lawrence DA, et al. (1996): Multiple mechanisms of PCB neurotoxicity. Proc Pacific Basin Conference on Hazardous Waste. Kuala Lumpur, Malaysia, 404-418.

6. Chen CJ, Yu ML, Rogan WJ, et al. (1994): A 6-year follow-up of behavior and activity disorders in the Taiwan Yu-cheng children. Am J Public Health, 84, 415-421.

7. Chrzanowska A, Graboń W, Mielczarek-Puta M, et al. (2014): Significance of arginase determination in body fluids of patients with hepatocellular carcinoma and liver cirrhosis before and after surgical treatment. Clin Biochem, 47, 1056-1059.

8. Chu I, Villeneuve DC, Yagminas A, et al. (1994): Subchronic toxicity of 3,3, 4,4, 5-pentachlorobiphenyl in the rat. I. Clinical, biochemical, hematological, and histopathological changes. Fundam Appl Toxicol, 22, 457468.

9. Dundar Y, Aslan R (1999): Bir antioksidan olarak vitamin E. Genel Tip Derg, 9, 109-116.

10. Ebner K, Couri D (1988): Aroclor 1254 treatment and fasting influences on rat liver mitochondrial carbamoyl phosphate synthesis with ADP and ATP. Toxicol Appl Pharmacol, 96, 75-84.

11. Ebner KV, Bergen WG, Braselton WE Jr (1987): Nitrogen deficits in aroclor 1254-treated rats. Fundam Appl Toxicol, 8, 89-96.

12. Erisir M, Beytut E, Ozan S, et al. (2003): Effects of dietary vitamin $E$ and selenium on arginase activity in the liver, kidney and heart of rats treated with high doses of glucocorticoids. Cell Biochem Funct, 21, 331-335.

13. Gallo-Torres HE (1980): Absorbtion, blood transport and metabolism of vitamin E. 170-267. In: Machlin LJ (Ed), Comprehensive Treatise. Marcel-Decker, New York.

14. Geyer JW, Dabich D (1971): Rapid method for determination of arginase activity in tissue homogenates. Anal Biochem, 39, 412-417.

15. Hansen LG (1999): The Ortho Side of PCBs. Occurrence and Disposition. Kluwer Academic Publishers, Boston.

16. Herrera E, Knopp RH, Freinkel N (1969): Carbohydrate metabolism in pregnancy. VI. Plasma fuels, insulin, liver composition, gluconeogenesis and nitrogen metabolism during late gestation in the fed and fasted rats. J Clin Invest, 48, 2260-2272.

17. Kimbrough RD, Krouskas CA (2003): Human exposure to polychlorinated biphenyls and health effects: A critical synopsis. Toxicol Rev, 22, 217-233.

18. Kutlu S, Colakoglu N, Halifeoglu I, et al. (2007): Comparative evaluation of hepatotoxic and nephrotoxic effects of aroclors 1221 and 1254 in female rats. Cell Biochem Funct, 25, 167-172.

19. Lowry OH, Rosenbrough NJ, Farr AL, et al. (1951): Protein measurements with the folin phenol reagent. J Biol Chem, 193, 265-275.

20. Lu CF, Wang YM, Peng SQ, et al. (2009): Combined effects of repeated administration of 2,3,7,8- tetrachlorodibenzo-p-dioxin and polychlorinated biphenyls on kidneys of male rats. Arch Environ Contam Toxicol, 57, 767-776.

21. Masuda Y, Kagawa R, Tokudome S, et al. (1979): Transfer of polychlorinated biphenyls to the foetuses and offspring of mice. Food Cosmet Toxicol, 16, 623-627.

22. Mayes BA, Brown GL, Mondello FJ, et al. (2002): Dermal absorption in rhesus monkeys of polychlorinated biphenyls contaminated with Aroclor 1260. Regul Toxicol Pharmacol, 35, 289-295.

23. Mayes BA, McConnell EE, Neal BH, et al. (1998): Comparative carcinogenicity in Sprague-Dawley rats of the polychlorinated biphenyl mixtures Aroclors 1016, 1242, 1254 and 1260. Toxicol Sci, 41, 62-76.

24. Metzger BE, Agnoli FS, Freinkel N (1970): Effect of sex and pregnancy on formation of urea and ammonia during gluconeogenesis in perfused rat livers. Horm Metab Res, 2, 367-368.

25. Park JR, Tappel AL (1991): Protein damage and lipid peroxidation: Effects of diethyl maleate, bromotrichloromethane and vitamin $E$ on ammonia, urea and enzymes involved in ammonia metabolism. Toxicol Lett, 58, 29-36.

26. Powers GS, Meister T (1982): Urea synthesis and ammonia metabolism. 251-263. In: Arias I, Popper H, Schachter D, Shafrits DA, editors. The liver: Biology and Pathobiology. Raven Press, New York.

27. Robertson LW, Hansen LG (2001): PCBs: Recent Advances in the Environmental Toxicology and Health Effects. The University Press of Kentucky, Lexington.

28. Safe S (1994): Polychlorinated biphenyls (PCBs): Environmental impact, biochemical and toxic responses, and implications for risk assessment. Crit Rev Toxicol, 24, 87-149.

29. Sonne C, Riget FF, Leat EHK, et al. (2013): Organohalogen contaminants and blood plasma clinicalchemical parameters in three colonies of North Atlantic Great skua (Stercorarius skua). Ecotox Environ Safe, 92, 245-251.

30. Takagi Y, Aburada S, Hashimoto K, et al. (1986): Transfer and distribution of accumulated $\left({ }^{14} \mathrm{C}\right)$ polychlorinated biphenyls from maternal to fetal and suckling rats. Arch Environ Contam Toxicol, 15, 709-715.

31. Ulbrich B, Stahlmann R (2004): Developmental toxicity of polychlorinated biphenyls (PCBs): A systematic review of experimental data. Arch Toxicol, 78, 252-268.

32. Van Larebeke N, Hens L, Schepens P, et al. (2001): The Belgian PCB and dioxin incident of January-June 1999: Exposure data and potential impact on health. Environ Health Perspect, 109, 265-273.

Geliş tarihi: 16.12.2015 / Kabul tarihi: 25.08.2016

Address for correspondence:
Dr. Ayşe Doğan
Bitlis Eren University
Academy of Medicine,
Department of Physiotherapy and Rehabilitation,
TR-13000, Bitlis, Turkey.
e-mail:aysedogan2003@yahoo.com

Address for correspondence:

Dr. Ayşe Doğan

Bitlis Eren University

Academy of Medicine,

TR-13000, Bitlis, Turkey.

e-mail:aysedogan2003@yahoo.com 